Article

\title{
LGBT in Turkey: Policies and Experiences
}

\section{Ceylan Engin}

Department of Sociology, Texas A\&M University, 311 Academic Bldg, 4351 TAMU, College Station, TX 77843-4351, USA; E-Mail: cengin@tamu.edu; Tel.: +1-205-821-8524

Academic Editor: Melanie D. Otis

Received: 10 July 2015 / Accepted: 15 September 2015 / Published: 18 September 2015

\begin{abstract}
While LGBT studies have been problematizing normative categories of sexuality primarily in Western cultures, the status of lesbian, gay, bisexual, and transgender (LGBT) individuals in non-Western societies remains understudied. This study examines the political attitudes toward LGBT individuals in Turkish society and explores the experiences of transgender individuals. While Turkey holds a strong economic position among Western countries, the situation of sexual minorities lags behind international standards. This study explores two research questions. First, what is the Turkish government's outlook for the LGBT community? Secondly, what kind of problems and challenges do trans-individuals experience in Turkey? This study first introduces a macro-level analysis of the politics of gender identity in Turkey by analyzing the debates of four deputies in the Turkish Parliament, each representing their parties' disparate viewpoints. Secondly, a micro-level analysis of previously collected interviews with twenty-five trans-individuals are also examined that shed light on the difficulties of being a trans-individual in Turkey. The content analysis shows that trans-individuals experience physical, sexual, and emotional violence, in addition to experiencing discrimination in employment, housing, and healthcare. The findings of this micro-level analysis elucidate the continuous discrimination, inequality, and violence that these individuals experience, while the macro-level analysis portrays the state's discriminatory policies toward LGBT individuals in Turkey.
\end{abstract}

Keywords: LGBT; Turkey; transgender; sexual minority; LGBT rights; political policy 


\section{Introduction}

Bihter, a transwoman from Ankara, was attacked with a knife by four men in April 2015. She received 172 stiches as a result of this incident [1]. The same year, Ipek, another transwoman, was also hospitalized after an attack by two men. She was beaten, stabbed, and left to die in a deserted area in Mersin [2]. Another transwoman B. E. was choked to death by a man. The perpetrator hid B. E.'s body under a pull-out couch and fled the city. B. E's body was later discovered by the police when her neighbors complained about the putrid odor coming from her apartment [3]. These horrific stories typify common experiences of transwomen in Turkey. Sexual minorities, and transwomen in particular, regularly experience sexual, physical, and emotional violence as a result of their sexual orientation and gender identity. This study explores the Turkish government's attitude toward the lesbian, gay, bisexual, and transgender (LGBT) community and the difficulties and challenges trans-individuals experience.

Turkey currently has the 6th largest economy in Europe, and the 17th largest in the world [4]. While Turkey holds a strong economic position among Western countries, the situation of sexual minorities lags behind standards that are claimed to be essential by human rights organizations like the General Assembly of the United Nations, the European Court of Human Rights, and the Supreme Court concerning LGBT issues. Although the Turkish Republic was founded as a secular state, traditional Islamic values remain omnipresent in most government and societal institutions. The influence of these values on Turkish policy making has resulted in further marginalization, stigmatization, and socially-disadvantageous outcomes for those who do not fit the dominant hetero-normative gender norms and sexual identities. This study asks two research questions. First, what is the Turkish government's outlook toward the LGBT community? Secondly, what kind of problems and challenges do trans-individuals experience in Turkey?

This study first introduces a macro-level analysis of the politics of gender identity in Turkey by analyzing the debates of four deputies in the Turkish Parliament, each representing their parties' disparate viewpoints. It then reviews a 2013 bill that promoted the improvement of lesbian, gay, bisexual, and transgender (LGBT) rights in Turkey. The findings indicate that the tenets and beliefs of political parties are strongly correlated with laws and regulations established by the Turkish Constitution. The government's macro level discrimination leads to detrimental consequences for LGBT individuals, while perpetuating gender inequality in Turkish society. Recent parliamentary debates on LGBT rights in Turkey portray a government that is failing to secure the civil and political rights of LGBT individuals.

Secondly, a micro-level analysis of previously collected interviews with twenty-five transgender individuals in Turkey is examined. Seventeen interviews were compiled through snowball sampling as part of a Social Justice and Art Project called Proudly Trans in Turkey. The rest of the interviews and testimonies are derived from stories published in LGBTI News Turkey. The content analysis shows that trans-individuals experience physical, sexual, and emotional violence in addition to experiencing discrimination in employment, housing, and healthcare. The findings of this micro-level analysis elucidate the continuous discrimination, inequality and violence that these individuals experience, while the macro analysis portrays the state's discriminatory policies toward LGBT individuals in Turkish society. Both macro-level and micro-level discrimination influence one another, creating perpetual gender inequality in Turkish society, which consequently leads to detrimental outcomes for LGBT individuals. 


\section{Historical Background}

Turkey has long been considered of strategic geographic importance because its landmass serves as a bridge between Europe and Asia. It is often viewed as an example of a modern Muslim state, with a secular, functioning democracy, in stark contrast to many other Middle Eastern governments that are run by dictatorships and religious fundamentalism [5,6]. Turkish culture is greatly influenced by European values as a result of its geographical position; however, traditional Islamic values also remain deeply ingrained in most of the country's social institutions [7]. In order to understand how gender inequality and a hetero-normative value system persist in Turkish society, it is pertinent to examine the political, economic, and social changes that Turkey has experienced since its formation in 1923.

Turkey was established as a secular democracy after the fall of the Ottoman Empire under the leader Mustafa Kemal Ataturk. The cultural and political climate of Turkish society was strongly influenced by the Kemalist movement that idealized modernization, secularization, and democracy, largely shaping what it meant to have a Turkish identity in the 20th century [8]. During the 1920s and 1930s, Turkish society experienced dramatic cultural, political, and economic transitions which resulted in the implementation of a wide range of social and political reforms. These policies aimed to weaken the power of religion, promote modernization, and spread a common sense of Turkish national identity $[8,9]$.

Ataturk's political reforms began with the abolition of the Caliphate and adopting the secular European model of the Swiss civil code. Modernization efforts also consisted of implementing secular public education, adopting the Latin alphabet, and changing the official national language to Turkish. Religious attire such as headscarves and fezzes were also banned in government institutions. Improving the position of women in society was another objective of the newly formed Turkish government. Polygamy was banned, and women were given equal access to divorce and inheritance. They became eligible to vote and to hold public office. These reforms aimed to weaken the power of religion in government institutions, infusing Turkish culture with Western liberal ideas to create a new type of citizenship and a modern society. The goal was to remove Islam from public affairs through state control [7,10]. However, anti-discrimination laws that would protect the rights of LGBT individuals were not included in these reforms.

\section{Current Status of the LGBT Population}

Although homosexual relationships were evident in the Ottoman era prior to the establishment of the Turkish republic, the emergence of non-heteronormative identities as a personal and collective identity did not occur until the 20th century $[11,12]$. This was mainly a result of rising globalization, industrialization, and urbanization in contemporary Turkey. As a result, there was a growing public visibility of homosexuality and gay identities with a mainstream understanding [12-14]. However, increasing visibility of same sex relations did not translate into an increasing public tolerance toward homosexuality. A global study conducted by Pew Research Center in 2013 reports that acceptance of homosexuality remains at a mere 9 percent. This is 5 percent lower than the year 2007. The low tolerance toward homosexuality has resulted in many forms of violence and discrimination against the LGBT population, both legally and socially [15].

While homosexuality is not banned in Turkish society, it is largely viewed as immoral and unnatural behavior. The government does not have anti-discrimination laws that prohibit discrimination on the 
basis of sexual orientation and gender identity. As a result, the discrimination and violence experienced by LGBT individuals remain institutionalized problems. For instance, the military specifically disapproves of gay males serving in the Turkish armed forces because it considers homosexuality a psychosexual disorder. The Turkish military have a long history of protecting the gendered binaries of the Turkish nation by excluding women and homosexual men. It is a social institution that promotes hegemonic masculinity by excluding feminine bodies from service. As Basaran points out, "the active/passive (penetrator/penetratee) binary correlates with the masculine/feminine binary regulating the dominant understanding of homosexuality" in Turkey, similar to some Caribbean and South American cultures [16].

Accordingly, the military performs medical inspections on those who are seeking an exemption from mandatory military service because of their sexual orientation. These inspections mainly include psychological testing, interviews, and rectal examinations. Some are also asked for photographs of themselves having homosexual intercourse and in which they can be seen as the passive partner [16-18]. Individuals who succeed in convincing military psychologists of their homosexuality are then given a curuk raporu; a certificate that labels biological men as "rotten." Homosexual men often apply for this ineligibility report because they fear experiencing homophobic violence in the military.

Individuals construct and reconstruct their gay, lesbian, bisexual, and transgender identities, creating their own narratives consistent with their culture and experiences. However, gay people are often stereotyped as effeminate and are presumed to hold passive roles in homosexual intercourse in Turkish culture $[12,13,16]$. While homosexual men who are not "feminine enough" are treated with skepticism by the military psychologists, feminine homosexual men are more likely to be considered to be ineligible for military service [16]. Gender inequality in the military is a persistent problem in and of itself, but it also has broader social repercussions due to the large role military service plays in defining masculinity in Turkish society.

The intersectional framework encourages us to think critically about how oppression manifests in societies. Social taxonomies of race, class, and gender discrimination are not independent from one another and should be examined as interlocking systems of oppression [19,20]. In predominantly-Muslim societies like Turkey, the role of religion plays a greater intersecting role with gender and sexuality than in most Western societies, resulting in alarming levels of institutionalized discrimination. LGBT individuals have a minority status because they have been systematically oppressed as a result of their sexuality and gender identity. Their oppression is a result of the patriarchal regime that punishes same-sex relations under Islamic beliefs. Religiosity contributes to the social and legal punishment of those who do not conform to rigid gender norms.

Individuals who fall outside the categories of socially-accepted norms of gender binaries are ostracized, often subjected to emotional and physical violence. The data available on sexual minorities are very limited and difficult to access. This is because once LGBT individuals reveal their nonconforming gender identity or sexual orientation, their most basic rights such as the right to life, to labor, to housing, to healthcare, and to education are greatly compromised [21]. Between January 2010 and November 2014, 47 individuals were killed in Turkey due to their sexual orientation and gender identity [22].

LGBT individuals also experience discrimination in employment. A study conducted by Mustafa Bilgihan Ozturk examines sexual orientation discrimination in the workplace by interviewing twenty lesbian, gay, and bisexual individuals in Turkey. He finds that most of the participants hide their sexual orientation from their families and workplace due to fear of abuse or violence. Meanwhile, individuals 
who did come out expressed experiencing severe discrimination, often resulting in termination of their jobs [23]. Other individual cases of discrimination have also been reported in the news media. For instance, police officer F.E was dismissed from his duties because he revealed his sexual orientation. When F. E. went to court to appeal for the state's discriminatory action, the Ministry of Internal Affairs provided him the following response: "The law foresees that these kinds of officers are to be cleaned out immediately!" [24]. There is lack of official data on hate crimes and discrimination against sexual minorities due to the systematic lack of attention by Turkish mainstream media outlets. As a result, most cases of hate crimes and discrimination against the LGBT population remain undocumented. The data on LGBT individuals are predominantly collected by volunteers of LGBT organizations [22].

The stories of transgender individuals are particularly disturbing. Transgender individuals are often subjected to physical violence as well as discrimination by the police and other members of Turkish society as a result of their gender identity. They are denied a safe working environment and are discriminated against on a daily basis $[23,25,26]$. The experiences of these individuals highlight the inequalities they face as a result of living in a homophobic culture that marginalizes and discriminates against them. The alienation that transgender individuals experience from their families and communities begins at an early age, and most often continues into an adult life in which there are often no other viable economic opportunities available aside from various types of sex work. The Human Resource Development Foundation (IKGV) reported that in 2011 there were about 4000 transgender sex workers working in Istanbul, constituting 15 percent of the total number of sex workers operating in Turkey [27].

The stigma, discrimination, and violence experienced by transgender individuals are, of course, not unique to Turkey. A low tolerance regarding their gender expression leads to a lack of employment opportunities for many transgender women and to living their lives below the poverty line [28,29]. While race, class, and gender can be seen as different axes of social structure, individual persons experience them simultaneously $[19,20]$. Social taxonomies of race, gender, religion, and class concurrently play a role in the experiences of LGBT individuals in Turkey. These categories operate together, influencing and shaping one another and consequently producing mechanisms of social inequality. For instance, racial and class differences can play a prominent role in transgender women's experiences [28,29]. Transgender women of color often experience multiple forms of discrimination as a result of their race, class, and gender identity.

Studies and reports conducted by LGBT and human rights organizations in Turkey [26,30,31] and research in other countries $[28,29,32]$ document that transgender individuals are subject to harassment, verbal attacks, arbitrary arrests, and physical violence. In addition, they are discriminated against in employment, education, housing, and healthcare. Transgender Europe's Trans Murder Monitoring Project reports more than 1500 trans-individuals were murdered in 57 countries since January 2008 [33]. These homicides were recorded by trans-organizations and activists. Most instances of trans-gender homicide take place in Central and South America. In Turkey there have been 34 reported murders of transgender individuals since 2008, more than any other European country. The murders range from multiple stabbings and shootings to death by castration and decapitation [33].

Although Turkey often prides itself for being a secular democracy with equal rights for women, when it comes to transgender women, the state lacks the protection of these individuals' rights. The general lack of tolerance toward LGBT individuals in Turkish society manifests itself in the form of hate crimes and discrimination. Research collected by Lambda, an LGBT activist organization in Turkey, surveyed 
116 transgender women through a snowball sampling in 2012. Approximately, 67.2 percent of the respondents identified their occupation as sex workers, and 82.8 percent (96 individuals) participated in sex work at least once in their lifetimes. The findings of the report also show that 90.5 percent of the respondents were subjected to physical violence and 92.2 percent had experienced verbal and sexual assault by police officials. In addition, 79.3 percent of transgender women reported experiencing physical violence, and 89.7 percent reported experiencing verbal and sexual assault from people they do not know [30].

Moreover, the Turkish legal system "under-punishes" those who commit hate crimes against LGBT individuals, often imposing only small fines or minor jail time [34,35]. The reductions in punishments are vindicated by judges because LGBT status is considered an abnormality in the eyes of the state law. Political leaders often intertwine gender identity with sexual orientation when they are discussing issues related to the LGBT population. Most state leaders also share the viewpoint that both homosexuality and trans-identity are immoral. In 2010, Aliye Kavaf, the former State Minister of the Affairs of Women and Families, said "homosexuality is a biological disorder, a disease. It is something that needs to be treated. Therefore I do not have a positive opinion of gay marriage" [36]. In 2012, Ankara mayor and a JDP Party member Melih Gökçek remarked:

Each society has its own moral values. Especially for our Turkish society, it is not possible for us to be together with the gay culture in Europe. It is also not possible to approve of this. How we have been brought up, our brand of morality, our views are a little different. I hope to God that in Turkey there will not be a gay and there should not be [37].

Furthermore, on June 2015, Efkan Ala, the former minister of Internal Affairs and a current Justice and Development Party (JDP) candidate for the parliament openly opposed gay marriage, stating that gay marriage is the destruction of humanity. He also criticized the Peace and Democracy Party (PDP) for promoting transgender and homosexual candidates for office. He stated, "For God's sake, look at these candidates that the PDP put forth. I can't even bring myself to say it. They have put forth candidates that our citizen cannot accept." He then argued that our society's morality and tradition rejects men marrying men and women marrying women [38].

In the next section, I discuss the data collection and methodology of this study. Drawing from parliamentary debates, I elucidate the Turkish government's contemporary political discourse toward the LGBT population. I then extend my analysis by examining the testimonials of twenty-five transgender individuals. This study will highlight the intersections between the institutionalized discrimination faced by LGBT individuals in general and the individual discrimination experienced by transgender individuals in particular.

\section{Methods}

This study first introduces a macro-level analysis of the debates of four members of parliament representing their parties in the Turkish government. Republican People's Party (RPP) Deputies Binnaz Toprak and Aykan Erdemir, PDP Deputy Ertugrul Kurkcu, and JDP Deputy Turkan Dagoglu, are analyzed concerning their attitudes towards LGBT rights in Turkey. These discussions took place on Wednesday 29 May 2013 at the Grand National Assembly of Turkey (GNAT). English translations of 
the parliamentary debates were available through LGBTI News Turkey. As a native Turkish speaker, I made small changes to the available translations if I felt a certain part of what the respondent said had been omitted. This is the first government discussion about a 2013 bill that promotes the implementation of LGBT rights in Turkey.

Secondly, a micro-level analysis of previously collected interviews with twenty-five trans-individuals are also examined that shed light on the difficulties of being a trans-individual, and particularly of being a trans-woman in Turkey. Seventeen of these interviews were part of a social justice project called Proudly Trans in Turkey, and were compiled by Gabrielle Le Roux with the support of Amnesty International and the Consulate General of the Netherlands. The collection of these interviews was made possible by trans-activists Sevval Kilic and Kemal Ordek's connections within the trans-community in Turkey. Participants were recruited through snowball sampling. The research respondents shared their intimate stories, considering themselves to be activists who chose to participate in this research in order to make their voices heard. These interviews were collected in March 2012 and made available as an online report by Amnesty International.

Each respondent was asked between twenty-five to thirty open-ended questions that capture a different aspect of the respondents' testimonies. These questions include some demographic inquiries about age, gender identity, and occupation, as well as other questions concerning the ways in which respondents are affected by hate crimes and discrimination, what the influence of religion is on their lives, what doors their gender identity opens and closes, what the condition of trans-individuals in Turkey is, what their dreams and aspirations are, and what repressive things they would like to see changed. Part of the interviews with each respondent were also video recorded with the exception of one individual who decided to reveal his name and voice but not his face. These video interviews include 18 video clips; ranging from three to $45 \mathrm{~min}$, totaling four hours and $30 \mathrm{~min}$. All the interviews were collected in the respondents' native language, Turkish. While the videos included English subtitles, I translated the rest of the interviews. I use these interviews in my analysis because the report is solely available in a raw interview format and the participants' responses have never been subjected to critical analysis under a sociological lens.

In addition to these participants, the remaining interviews and testimonies of Turkish trans-individuals were retrieved from a website called LGBTI News Turkey. LGBTI News Turkey is a volunteer run organization that is dedicated to providing English translations and sources on issues related to LGBTI individuals living in Turkey. These testimonies strongly capture the difficulties of having a trans-gender identity in Turkish culture. It should be noted that the data that is available on sexual minorities in Turkey is very limited and very hard to access. This study does not aim to generalize to the experiences of all trans-individuals in Turkey. Instead, it aims to share some of the difficulties trans-people experience as a result of living in a staunchly heteronormative culture.

The data used for the content analysis in this study thus consist of a total of twenty-five testimonials from two different sources. The study is focused on the intersection of micro-level data provided by these individual accounts and macro-level political attitudes that have a distinct impact on the lives of LGBT individuals. The parliamentary debates focus on the larger issue of institutional discrimination against LGBT individuals in Turkey, whereas the interviews encompass issues facing the general transgender population. 


\section{Findings}

\subsection{Political Parties' Attitudes and Policies toward LGBT Individuals}

The ideals and beliefs of political parties in the Grand National Assembly of Turkey are strongly correlated with laws and regulations that are established by the Turkish constitution. There are currently a total of 550 senate members in the Grand National Assembly. Elected political parties include (1) Justice and Development Party (JDP), with 258 members; (2) Republican People's Party (RPP), with 132 members; (3) Nationalist Movement Party (NMP), with 80 members, and Peace and Democracy Party, (PDP) with 80 members [39]. The distribution of the female members among political parties is shown in Table 1 (17.82 percent, totaling 98 individuals).

Table 1. GNAT deputy distribution by gender [39].

\begin{tabular}{cccccc}
\hline \multirow{2}{*}{ Party Name } & \multicolumn{2}{c}{ Female Members } & \multicolumn{2}{c}{ Male Members } & \multirow{2}{*}{ Party Total } \\
\cline { 2 - 4 } & Count & Percentages & Count & Percentages & \\
\hline AKP & 41 & $15.89 \%$ & 217 & $84.11 \%$ & 258 \\
RPP & 21 & $15.91 \%$ & 111 & $84.09 \%$ & 132 \\
NMP & 4 & $5 \%$ & 76 & $95 \%$ & 80 \\
PDP & 32 & $40 \%$ & 48 & $60 \%$ & 80 \\
Total & 98 & $17.82 \%$ & 452 & $82.18 \%$ & 550 \\
\hline
\end{tabular}

The political speeches of four Turkish parliamentary members: Binnaz Toprak (RPP Deputy), Aykan Erdemir (RPP Deputy), Ertugrul Kurkcu (PDP Deputy), and Turkan Dagoglu (JDP Deputy) are analyzed concerning their attitudes towards LGBT rights in Turkey. This was the first government discussion in regard to LGBT rights that took place in the Turkish Government. Members of the Nationalist Movement Party (NMP) were not present during the discussions and remained absent from the voting. On 12 February 2013, Binnaz Toprak with the support of 54 deputies of CHP requested a Parliamentary inquiry in order to determine the problems of lesbian, gay, bisexual, and trans individuals in accordance with Article 98, and standing rule 104 and 105. The proposed bill aimed to investigate the causes of these problems in terms of political, economic, social, and psychological aspects so as to prevent discrimination and violence against LGBT individuals. Their motion included a brief description of types of violence, discriminatory practices, and stigmatization experienced by LGBT individuals both on the state and the individual level [40].

The Republican People's Party's introductory bill criticized the Turkish constitutional law of equality and argued that the law is not holding up to the standards of the European Union and the United Nations clauses on prohibiting discrimination against LGBT individuals. Article 10 of the Constitution proclaims that, "Everyone is equal before the law without distinction as to language, race, color, sex, political opinion, philosophical belief, religion and sect, or any such grounds" [41]. Supporters of the proposed bill argue that "Article 10 and Article 70" of the Constitution of the Republic of Turkey, and "Article 5" of the Labor Law should also broaden its categories to sexual minorities in order to reduce gender discrimination. Legal guarantees on behalf of sexual orientation and gender identity must be provided for LGBT individuals [40]. 
On behalf of the Republican People's Party (RPP), both deputies Toprak and Erdemir spoke in favor of the proposed bill. Erdemir stated:

They could not find a place for my child in this huge world,' distinguished members of the parliament, these are the words of the mother of our citizen with a different sexual orientation who was murdered in September 2010 in Bursa. Today we are talking about opening a tiny space in this huge world to fit these parents' children. Is there a tiny space for the ones who have been murdered by 12 stab wounds, 40 stab wounds, or for the ones whose bodies have been inflicted by wounds that will not heal, whose wounded hearts will not heal [42]?

Erdemir (2013) then discussed the progress of LGBT rights in Turkey by saying,

(...)The world is changing. Taboos are breaking. A better, freer, and more equal world is possible. Unfortunately, Turkey is not moving forward in the same speed as the Western systems in regard to freedom of gender expression (...) As Republican People's Party, we wish that in Turkey, we would not move with anger and hate. As we have also engaged in our election report; we are demanding the creation of a legal arrangement for the fight against discrimination and hate crimes as soon as possible. We want that, we hope that one day in the huge agenda of the assembly a tiny space and time will be created for hate crimes [42].

Before Erdemir could finish his speech a deputy of the Justice and Development Party (JDP) Ibrahim Korkmaz interrupted Erdemir's speech three times by shouting, "What you are talking about is immoral". Korkmaz left the assembly room without hearing the rest of Erdemir's speech. The Peace and Democracy Party (PDP) deputy Ertugrul Kurkcu also expressed his supportive views of the Toprak's bill proposal by stating that, "There is a group of people who are pushed to the margins of society because of public bias, traditional behaviors, legends, and negative myths. Special precautions need to be taken in order to make them equal with the rest of the society. This is why this inquiry is necessary" [43]. In addition, Kurkcu argued that the state cannot protect people's rights if it neglects or denies the rights of certain groups. To support his point of view he argued:

When we said, we are Kurds in Sisli and gays in Taksim during gay pride, media outlets propagandized against this said, "they are homos too". In truth, it would not have matter even if I were; however, the issue here is to ask for protection of the rights of homosexuals even if one does not consider himself as one. The day we protect the rights of those who are not like us, then we are going to see a real change in this country (...). Otherwise, things will stay the same. You will continue to stone homosexuals, and in places where you cannot stone them, you will insult them and leave the assembly room [43].

After Kurkcu's speech, Turkan Dagoglu, a physician, spoke against the proposal of Toprak's motion on LGBT equality on behalf of the Justice and Development Party. She began her speech by questioning what it means to have an LGBT identity, asking whether it is a biological deficiency, a sociological appearance, or a psychological problem. Dagoglu stated that "women marrying women, or men marrying men is not a right, on the contrary it is a proposal that converts accepted sexual understandings that smooths the path of degeneracy of society" [44]. The JDP deputy continued her speech by arguing that 
LGBT identity is an abnormal behavior that is proven by research that was presented in 1972 and 1992. She argued that:

Researches on this topic has been done previously in both in the US in 1972, and by the European psychological association in 1992. They found that what we consider an LGBT status is not normal behavior [44].

Dagoglu also labeled homosexuality as a degeneration of society by stating:

Affiliates of the JDP, regularly express valuing humans simply because they are humans, treating everyone equal under the law, loving every creature because of the creator. Social measures that are taken are not for a specific sexual orientation, it is for the benefit of all humanity. Nonetheless, these attributes cannot be used as a door opening to lifestyles that our society disapproves of or as an encouragement for the sort of behavior that triggers the degeneration of the population, and cannot be assessed as a criterion for democracy [44].

The suggested bill that promoted the inquiry into LGBT individuals' problems and needs did not receive enough votes that day in the parliament. Only 59 parliamentary members voted in favor of the bill that would safeguard the rights of the LGBT population. No further developments or measures have been taken by the Turkish government since the parliamentary debates to protect and recognize the rights of the LGBT citizens. In fact, current Minister of Family and Social Policy, Aysenur Islam noted homosexuality as preference instead of sexual orientation [45]. It should be noted that while gender identity and sexual orientation should be treated as distinct identity categories, the Turkish political representitives do not make this distinction in their discourse. Instead, they often treat transgender status, a distinct gender identity, similar to having a gay, bisexual, or a lesbian sexual orientation.

Some scholars argue that LGBT rights have not been recognized in Turkish society because LGBT issues challenge the Justice and Development Party's modern conservative agenda. JDP's conservatism considers the family to be the primary social institution and sees its values and traditions as essential to nation building and maintaining peace. Modern values are thus perceived as a threat to the disintegration of traditional social values. Many conservative political leaders emphasize the need for Westernization to be a selective process in order to prevent social degeneration in Turkish society [46]. As JDP political representatives and supporters such as Dagoglu, Islam, Ala, and Kavaf confirm in their speeches, sexual deviance is considered a gateway to the degeneration of society. As a result, the recognition and protection of LGBT rights have not been granted because such legislation would defy the JDP's conservative democratic identity. In a similar way, the Nationalist Movement Party (NMP) has remained silent on issues related to homosexuality and LGBT rights. However, they showed their support for the JDP by not voting in favor of the bill that would improve the rights of LGBT individuals. The NMP's presidential candidate Ekmelettin Ihsanoglu has also denied that homophobia was a universal issue [47]. According to both the JDP's and the NMP's conservative agenda, traditional family values trumps civil rights issues such as LGBT rights. Instead of ameliorating LGBT issues, the government considers legitimizing civil rights a deterioration of moral values.

Although homophobic attitudes are not limited to conservative circles, representatives of both the RPP and the PDP have been more prone to form strategic alliances with LGBT rights organizations and promoting LGBT candidates in local and national elections. Two years ago, Kemal Kilictaroglu, the 
leader of the RPP, stated in regard to gay marriage and gay political representation: "I do not think the society of Turkey has reached this level of maturity. Because of this, it is not possible for the RPP to declare a gay candidate as mayor or establish gay marriage in a legal framework" [48]. Despite his previous response, Kilictaroglu later had met with representatives from the Platform for LGBT Political Representation and Participation. Social Policies, Sexual Orientation and Gender Identity Studies Association (SPoD) also prepared an LGBTI Rights Pledge and called on political candidates and parties to work towards the inclusion of LGBTI individuals in decision and policy-making before the 2015 general elections. Sixty-four candidates for parliament, twenty-three from the RPP, twenty-five from the PDP, and two from other parties, signed SPoD's LGBTI Rights Pledge before the recent elections and promised to safeguard the rights of the LGBTI individuals [49].

Moreover, the Peace and Democracy Party and its leader Selaattin Demirtas have been actively speaking to eliminate discrimination on the basis of sexual orientation and gender identity. The PDP is known as a voice of the Kurdish minority, aiming to stop discrimination against Kurds in Turkey. The party's political agenda has been a pluralist form of government that represents economic, political, and social demands of marginalized populations such as Kurds, women, workers, Alevis, and LGBT individuals [47]. The PDP and its representatives have been stressing the importance of fighting against all ethnic, religious, sexual, gender, and class discrimination. At a recent press conference, in regards to discrimination against LGBTI individuals, Demirtas said:

LGBTI individuals who are targeted, killed, repressed, or ostracized because of their sexual orientations and sexual identities are ignored by the system. LGBTIs' mere existence is seen as a crime. Homophobia and transphobia are fed. "New Life" calls for equal citizenship rights for all sexual identities to live free and honorable lives in society without fear of discrimination [47].

The Turkish government continues to deny civil rights to those who hold an LGBT identity and homosexuality remains to be considered a disease and abnormality in the eyes of the Turkish government. The state justifies its discriminatory actions by supporting their arguments with outdated scientific evidence on sexuality, or religious arguments considering homosexuality as immoral. Consequently, the state also fails to address the needs of this particular population. While a small minority of the parliamentary members promotes the rights of the LGBT individuals, the majority of the deputies are not supportive of homosexuality. These parliamentary debates elucidate the hetero-normative values that remain very present in the country's social institutions.

\subsection{Experiences of Transgender Individuals in Turkey}

The next part of this study discusses the findings of a micro-level analysis of experiences of twenty-five transgender individuals. Among the twenty-five respondents, seven identified themselves as transsexual women, one identified as a female-to-male transsexual, fourteen referred themselves as transwomen, one defined himself as a trans-man, and two referred to their gender identities as just "trans". For the purposes of this study, the word transgender is used interchangeably with the words transsexual, trans-woman, trans-man, and trans, when referring to individuals in this study. Eight individuals identified themselves as transsexual. However, it is not clear for some individuals whether they have gone through 
sexual reassignment surgeries, are undergoing hormone therapy, or they prefer solely cross-dressing. Although every trans-person's story is unique for each individual, various experiences stand out when comparing the experiences of transgender individuals in Turkey. Physical violence, discrimination, emotional and verbal abuse on both the state and individual level are among the common themes of experiences of transgender individuals in Turkey because of their gender identity or sex worker status.

When individuals were asked about their gender identity, some expressed that they do not like to stereotype themselves. For instance, Buse said, "I am who I am. I am labeled as trans so I'm just carrying the label" [50]. Destina said, "I am a heterosexual transsexual in full acceptance of the world" [50] and Belgin said, "I'm a transsexual woman. I'm a woman. I'm a woman in my mind and soul" [50]. The interviewees' ages range from 24 to 57 . However, three of the women specifically did not want to provide their ages. Selay noted, “I don't want to tell my age. I'm exactly as old as I look and not so old as you see" [50]. Three of the trans-women also identified their Kurdish background. The respondents' occupations consisted mostly of activists, sex workers, or a combination of both (Table 2).

Table 2. Demographic distribution.

\begin{tabular}{|c|c|c|c|c|}
\hline Names & Gender Identity & Age & Race & Occupation \\
\hline Aras & Transman & 28 & Turkish & Activist \\
\hline B.E. & Transwoman & Unknown & Turkish & Sex Worker \\
\hline Belgin & Transsexual woman & 57 & Turkish & Sex Worker/Activist \\
\hline Bihter & Transwoman & Unknown & Turkish & Sex Worker \\
\hline Buse & Trans-woman & Did not want to answer & Turkish & Sex Worker/Activist \\
\hline Demet & Transsexual woman & 50 & Turkish & Ex-Sex worker/Activist \\
\hline Demet Y. & Transwoman & Unknown & Turkish & Activist/Sex Worker \\
\hline Deniz & Transwoman & 28 & Turkish & Activist/Part-time Sex Worker \\
\hline Destina & Transsexual woman & Did not want to answer & Turkish & Sex Worker/Activist \\
\hline Doga & Transwoman & Unknown & Turkish & Former Commander \\
\hline Esmeray & Transsexual woman & 38 & Kurdish & Sex Worker/Actor/Activist \\
\hline Eylul & Transwoman & 25 & Turkish & Sex Worker/Activist \\
\hline Eylul Cansin & Transwoman & 24 & Turkish & Sex Worker \\
\hline Gani & Transwoman & 40 & Turkish & Sex Worker, Activist \\
\hline Gorkem & Transwoman & Unknown & Turkish & Sex Worker \\
\hline Ilksen & Trans & 26 & Turkish & Musician/Activist \\
\hline Inan & FTM Transsexual & 24 & Turkish & Activist \\
\hline Ipek & Transwoman & Unknown & Turkish & Sex-Worker \\
\hline Oyku & Transsexual woman & 41 & Turkish & Ex-sex worker/Activist \\
\hline Ruzgar & Trans & 24 & Turkish & Activist \\
\hline Selay & Transsexual Woman & Did not want to answer & Turkish/Kurdish & Sex Worker/Activist \\
\hline Sema & Transwoman & 24 & Turkish & Student/Activist \\
\hline Sevval Kilic & Transwoman & 50 & Turkish & Activist \\
\hline Sinem & Transsexual & 39 & Turkish/Kurdish & Sex Worker/Activist \\
\hline $\mathrm{Su}$ & Transwoman & 26 & Turkish & Sex Worker/Activist \\
\hline
\end{tabular}


Family abuse tends to be a common problem in transgender individuals' lives. Coming out to their families is a very stressful event for transgender individuals. Since traditional norms of gender binaries are still a prominent part of Turkish culture, even the person's own biological family can turn to violence once individuals verbally express their nonconforming gender identity. Sinem's eyes got watery when she talked about the brutal tragedy she experienced when she first opened up to her family:

After I told my parents about my gender identity, the family assembly got together and agreed upon my death. I was chained to a twelve meter iron chain for 3 days. I was also terribly beaten. On the third day, my older brother unchained me and threw me out at the railroads and told me I had a better chance to survive there [50].

Another woman named $\mathrm{Su}$ who also currently works as a sex worker and an activist told a similar story:

After I came out to my parents, my brother threatened to kill me. He cut my hair and I was chained to a radiator for eight months. The chain was only long enough to reach the toilet. I lived like that, without any human interaction. It was a very traumatic experience for me [50].

It is not uncommon for trans-individuals to experience violence and isolation from family members. Most of the respondents explained that they feel closer to the trans-community than to their biological parents. For instance Sinem claimed that, "What life taught me is that a trans-woman's only real friend is another trans-woman. Trans-women supported me in my most difficult times. They are the reasons why I am still alive" [50]. On the other hand, not every transgender individual experiences violence in their family homes. Some parents are prone to empathize with their children in addition to providing emotional, financial, and legal support. Families that are supportive of their children's transition period have positive effects on their children's development and can alleviate much of the pressure of living in a heteronormative culture. For instance, Pinar, a mother of a trans-woman asserts that:

The thing we most want for our children is for them to be able to act with more freedom in this country we live in. We are fighting for our kids legal rights because all of our kids are victimized. We have children that are afraid to go outside because they are treated roughly in every step they take. We do not want our children to go through this [50].

The isolation, discrimination, and violence transgender individuals experience continues in their adult life and often results in participating in sex work. The Turkish government further facilitates job discrimination of transgender individuals by not employing policies that support the freedom of gender identity and expression. These inequalities block transsexual individuals' paths to economic opportunity and social mobility. Destina notes that:

All trans tell similar stories. I experienced a lot of work discrimination. I was fired from multiple jobs specifically because of my gender identity. I had no other choice but to participate in sex work. The good part is that I have united my body and soul. The bad part is I'm forced to do sex work and that's horrible. Being a woman and having to be a sex worker tears me apart inside [50].

$\mathrm{Su}$ also agrees with Destina by saying, "I engage in sex work because of survival needs. It's not something I would like to be doing" [50]. Demet, an ex-sex worker and currently a human rights activist, 
argued that trans-individuals have very limited working opportunities. Her only alternative thirty years ago was to work as a sex worker and this still continues to be the case for most trans-woman in Turkey today. Sinem (a former teacher currently working as a sex worker) also protested the fact that she was discriminated against at her workplace as a result of her transgender identity. Consequentially, she was left with no choice but to return to work as a sex-worker. She said:

Even though I have been experiencing many types of discrimination as a result of my gender identity, I graduated from university and became a teacher. While I was on my fourth year of teaching in Mus, Ministry of Education began preliminary field investigation on behalf of me. My teaching location was changed multiple times. I loved my job, but because of the endless pressures I experienced, I resigned from my job crying. I knew my only other alternative would to be back to participating in sex work [50].

Doga, a former military commander faced discrimination and inequality once she came out as trans. She said:

I was a commander in the state's military at age 18 . The youngest soldier was 21 . There were other soldiers in lower ranks. At age 18, I was above so many people in this ridiculous way. They expected me to manage them, and be a harsh man. I was successful in terms of work. Because I worked as a gendarmerie, we dealt with judicial things such as traffic accidents and murders. I had all these badges. Even though I was so successful, when I came out as trans, all those certificates, praises, badges were zeroed [51].

Although this study does not account for every transgender individual, the findings also correlate with previously collected research on transgender individuals. Collected research both in Turkey [26,30] and in other countries $[29,32,52]$ elucidate that transgender individuals work in dangerous environments and regularly experience harassment, verbal and emotional abuse, violence, and arbitrary arrests in addition to the fact that they frequently experience discrimination in employment, housing, education, and health care.

Some Turkish transwomen have a more positive and professional outlook of their work regardless of the social pressures they experience. These results also support Don Kulick's findings on transvestites who participate in prostitution in Brazil [29]. Regardless of the dangers of their work environments, Kulick's respondents did not perceive being a sex-worker as a demeaning occupation. Some of them stressed that they like the fact that they can be their own boss. They also believe that sex work provides a greater opportunity to earn a higher income than other types of employment that are available to them. Similarly, Turkish trans-woman Eylul argued that:

I've been working in a variety of jobs since I was 14, including fast food chains, restaurants, hotels, etc. I remember a time when I worked for 20 hours and got paid 20 liras (about 13 dollars). But I've been a sex worker for the last two years and I'm making good money. I like this job since I earn what I deserve [50].

Selay, also transsexual sex worker living in Istanbul said:

I'm a sex worker. This is what I've studied for the past fifteen years and that's why I'm good at it. I respect others in this industry. Some are forced to do it. They cry and take drugs to 
tolerate it, but I'm proud of what I do and I can shout it out. So I want to keep doing my job but I want protection and a safety net because ultimately I am providing a service [50].

Whether these women consider their job oppressive or empowering, safety is a major concern that all of them have in common. Many of the respondents expressed the fact that they live with a constant fear of death. Some of the individual comments capture this sense of anxiety. For instance Destina states that "Whether or not I work on the street, a violent act towards a friend affects me too. I know if it's happening to one person today, and it might happen to me tomorrow" [50]. Selay also states that "I feel afraid to go out because anything can happen at any time. We are abused all the time”. Sinem also said:

"Hate crimes control my life. I've been working as a sex worker for thirteen years, and each night before I go out, I take a last look at my house. Each night without exception I feel like I won't be back. I put many of my flat mates and best friends underground. I buried them myself" [50].

Additionally, some women express their sadness at the fact that these crimes often go under-punished. Esmeray, a former sex worker and a current sex activist, stated that:

The murderer can easily get off by saying "I visited this person thinking that it was a she but it turned out to be a he and I killed him". And the judge takes that into account and extenuates the punishment. There are so many cases of this. But nowadays most cases go unclosed without even being investigated [50].

Agreeing with Esmeray, Buse also protested this phenomenon by saying,

We live in a country where people murder trans-individuals and justify it by saying "I killed her because she was transgender" [50].

Inan, one of the trans-men, expresses these feelings in regard to hate crimes:

As long as it's not obvious that I'm a trans, and that I refuse to identify my gender identity, I am safe as a part of the masculinity. But at the moment that I come out or my gender identity is revealed, I became subject to violence [50].

When individuals were asked what repressive practices they would like to see changed, they provided some intriguing answers. The conventional family, religion, and heteronormativity were among the common themes. Aras said, "The institution of family. We are haunted by it. It's like an evil curse, a great burden that can't easily get rid of" [50]. Inan expressed that he finds masculinity to be the most repressive, arguing how "patriarchal politics impose male pressure to be more masculine" [50]. Deniz and Belgin portrayed similar views to Inan and found the heterosexual and male-dominated lifestyle to be the most repressive aspect of Turkish society. In addition, Sevval Kilic stated that, "I find religion to be the most repressive. After that the government, and then the traditional family structure. These institutions constantly tell you what is right and what is wrong" [50].

In regard to the current status of transgender individuals in Turkey, most respondents had a negative outlook and argued that the treatment of trans-individuals is deteriorating. For instance, Inan argued that most trans-individuals in Turkey are unhappy because they do not have any space to live freely. 
He said, "We do not want much. Like we want to be able to walk on the road or ride the bus (without getting harassed)" [50].

Moreover, LGBT individuals also suffer from increased risk of suicide and depression. Studies show suicide rates for LGBT youth are higher than their heterosexual counterparts. Attempted suicide is even higher for transgender individuals [53-55]. A Turkish transwoman Eylul Cansin committed suicide in January in 2015 by jumping off of the Bosphorus Bridge in Istanbul. Cansin left a suicide video saying she is doing what everyone wanted her to do. In tears, she recorded:

I was born in 1992. Now I must be 24 and I'm ending my 24 years. Kisses to everyone. I couldn't. I couldn't because people did not let me. I couldn't work, I wanted to do stuff, I couldn't...You get me? They impeded with me many times; they made me suffer a lot. I leave everyone alone with God and now I'm going to the Bosphorus Bridge. Kisses to all, God bless you [56].

In addition to Cansin, a trans-boy named Okyanus Efe Ozyavuz from Izmir, trans-activist Figen from Mersin and an Iranian gay refugee in Denizli were among the ones who committed suicide in 2015 [43]. Previous studies point out that institutionalized and internalized homophobia and discrimination can lead to serious mental health problems [57-59].

At the micro level, the findings of this study demonstrate common difficulties of transgender individuals in Turkey. First, a lack of family support combined with cultural homophobia that is present in Turkish society creates socially disparate outcomes for transgender individuals. Experiencing violence and discrimination as a result of their gender identity, respondents often struggle to secure employment opportunities and thus participate in prostitution out of economic necessity. The low tolerance towards their gender identity can result in anything from verbal attacks to physical violence to brutal homicides.

Discrimination and violence trans-individuals experience at the micro-level continues at the macro-level. Lack of safety is a predominant concern for transgender individuals. The Turkish government's criminalization policies toward prostitution combined with lack of protection of civil rights perpetuate the economic deprivation, social marginalization, and violence against transgender individuals.

\section{Conclusions}

LGBT rights in Western societies have been progressing more rapidly since the 1970s, while public attitudes and government policies in Turkey are not making such rapid strides toward tolerance. This study examines political attitudes toward the LGBT population in Turkish society by first analyzing the debates of four cabinet members, each representing their party's point of view. The results of the parliamentary debates show that the majority of Turkish representatives are not supportive of LGBT rights. As a result, the Turkish government fails to protect the rights of sexual minorities. This study also documents twenty-five transgender individuals' experiences of discrimination, abuse, and violence as a result of living in a staunchly hetero-normative culture.

One of the limitations of this study is the possibility of community bias. Since most participants in the secondary-data analysis identified themselves as activists, they may have produced biased results. The small number of observations is another limitation in this study. A larger sample size and the selection of individuals from all ethnic, age, and class groups, proportionally, may reduce this sampling 
bias. Further research that encompasses a larger number of interviews with a probability sampling technique to produce data that is representative of the LGBT population in Turkey is also needed. However, quantitative research on hidden populations are difficult to obtain since these populations are not included in large datasets. While this study methodologically poses challenges, it still enables us to learn about a vulnerable population that is outside mainstream social research and is extremely difficult to access.

Although this micro level analysis cannot be generalized for every trans-individual in Turkey, an overwhelming majority of them work in dangerous environments and regularly experience harassment, violence, and abuse. They also experience discrimination in employment, housing, education, and healthcare. This is not a unique circumstance to transgender people in Turkey. Global research on transgender individuals also supports this phenomenon. Accordingly, certain reforms and policy changes need to be adopted by the Turkish government in order to reduce discrimination and safeguard the equal protection of LGBT individuals in general and trans-individuals in particular.

One of the reforms that would ameliorate the rights of LGBT individuals is the adoption of anti-discrimination laws on the basis of sexual orientation and gender identity. "Article 10 and Article 70" of the Constitution of the Republic of Turkey, and "Article 5" of the Labor Law should aim to broaden its categories to sexual minorities in order to reduce discrimination on the basis of sexual orientation and gender identity. Secondly, proportional legal punishment of those who commit crimes against the LGBT population is crucial for combating hate crimes. The government also needs to expand social services available to the LGBT population such as suicide prevention, job placement, and housing. Finally, the state needs to improve medical and health care services that serve the LGBT population's needs such as hormone therapies, gender reassignment surgeries, and unbiased treatment. These revisions in the law are crucial for LGBT individuals to safeguard their rights to life, labor, housing, healthcare, and education.

\section{Conflicts of Interest}

The author declares no conflict of interest.

\section{References}

1. LGBTI News Turkey. "Knife Attack Against Tranwoman." 2015. Available online: http:// lgbtinewsturkey.com/2015/05/01/biter-assaulted-almost-severing-hand/ (accessed on 15 May 2015).

2. LGBTI News Turkey. "Transphobic Attack Against Sexworker in Mersin.” 2015. Available online: http://lgbtinewsturkey.com/2015/03/02/transphobic-attack-against-sex-worker-in-mersin/ (accessed on 15 May 2015).

3. LGBT News Turkey. "Transwoman Murdered and Hidden Under Couch." 2015. Available online: http://gbtinewsturkey.com/2015/01/30/trans-woman-murdered-and-hidden-under-couch/ (accessed on 15 May 2015).

4. Kolesnikov, Ivan. "World GDP Ranking 2015.” 2015. Available online: http://knoema.com/ nwnfkne/world-gdp-ranking-2015-data-and-charts (accessed on 1 June 2015).

5. Davutoğlu, Ahmet. "Turkey’s Foreign Policy Vision: An Assessment of 2007." Insight Turkey 10 (2008): 77-96.

6. Kirişci, Kemal. "Turkey's 'Demonstrative Effect' and the Transformation of the Middle East." Insight Turkey 13 (2011): 33-55. 
7. Saktanber, Ayse. Living Islam: Women, Religion and the Politicization of Culture in Turkey. New York: I. B. Tauris, 2002.

8. Pope, Nicole, and Hugh Pope. Turkey Unveiled: A History of Modern Turke. New York: The Overlook Press, 1997.

9. Shissler, Ada Holland. “If You Ask Me': Sabiha Sertel's Advice Column, Gender Equity, and Social Engineering in Early Turkish Republic." Journal of Middle East Women's Studies 3 (2007): $1-30$.

10. Eligür, Banu. The Mobilization of Political Islam in Turkey. Cambridge: Cambridge University Press, 2014.

11. Murray, Stephen O. "Homosexuality in the Ottoman Empire." Historical Reflections Historiques 33 (2007): 101-16.

12. Ozyegin, Gul. "Reading the Closet through Connectivity." Social Identities 18 (2012): 201-22.

13. Bereket, Tarik, and Barry D. Adam. "The Emergence of Gay Identities in Contemporary Turkey." Sexualities 9 (2006): 131-51.

14. Özbay, Cenk. "Nocturnal Queers: Rent Boys' Masculinity in Istanbul.” Sexualities 13 (2010): 645-63.

15. Pew Research Center. "The Global Divide on Homosexuality." 2013. Available online: http://www. pewglobal.org/2013/06/04/the-global-divide-on-homosexuality/ (accessed on 15 March 2015).

16. Basaran, Oyman. "'You Are Like a Virus': Dangerous Bodies and Military Medical Authority in Turkey." Gender \& Society 28 (2015): 562-82.

17. Azizlerli, Emre. "Proving You're Gay to the Turkish Army." BBC News, 26 March 2012. Available online: http://www.bbc.com/news/magazine-17474967 (accessed on 10 July 2013).

18. Cengiz, Orhan Kemal. "Gay in the Turkish Military." Almonitor, 2013. Available online: http:/www.al-monitor.com/pulse/fr/originals/2013/08/Gay-turkish-army-legal-rights.html\# (accessed on 30 September 2013).

19. Crenshaw, Kimberle. "Mapping the Margins: Intersectionality, Identity Politics, and Violence against Women of Color.” Stanford Law Review 43 (1991): 1241-99.

20. Andersen, Margaret, and Patricia Hill Collins. Race, Class, \& Gender: An Anthology. Belmont: Wadsworht Publishing Company, 1992.

21. Çakirlar, Cüneyt, and Serkan Delice. Cinsellik Muammasi: Turkiye'de Queer Kultur ve Muhalefet. Istanbul: Metis Yayinlari, 2012.

22. Bilginsoy, Zeynep. "Evaluating Hate Murders Based on SOGI in TURKEY: Shortcomings and Proposals." Available online: http://gbtinewsturkey.com/2014/11/30/infographic-hate-murders/ (accessed on 5 June 2015).

23. Ozturk, Mustafa Bilgehan. "Sexual Orientation Discrimination: Exploring the Experiences of Lesbian, Gay and Bisexual Employees in Turkey." Human Relations 64 (2011): 1099-118.

24. Karakas, Burcu. "Bu Tür Memurlar Hemen Ayıklanır!” Milliyet, 2014. Available online: http://www.milliyet.com.tr/bu-tur-memurlar-hemen-ayiklanir--gundem-1897738/ (accessed on 5 June 2015).

25. Dogan, Mehtap. “On IDAHOT, LGBTI Individuals Face Countless Problems in Turkey.” 2015. Available online: http://gbtinewsturkey.com/2015/05/15/on-idahot-lgbtis-face-countless-problemsin-turkey/ (accessed on 1 June 2015). 
26. Kaos GL Dernegi. “2013 Yilinda Turkiye'de Gerceklesen Homofobi ve Transfobi Temelli Nefret Suclari Raporu.” 2013. Available online: http://www.kaosgldernegi.org/resim/yayin/dl/nefret_ sulari_raporu_2013.pdf(accessed on 10 June 2015).

27. Insan Kaynagini Gelistirme Vakfi. "Seks Iscileri ve Yasalar: Turkiye'de Yasalarin Seks Iscilerine Etkileri ve Oneriler.” 2011. Available online: http://amargigroupistanbul.files.wordpress.com/ 2012/05/text1.pdf (accessed on 5 September 2013).

28. Sausa, Lydia A., JoAnne Keatley, and Don Operario. "Perceived Risks and Benefits of Sex Work among Transgender Women of Color in San Francisco.” Archives of Sexual Behavior 36 (2007): $768-77$.

29. Kulick, Don. Travesti: Sex, Gender, and Culture Among Brazillian Transgendered Prostitutes. Chicago: University of Chicago Press, 1998.

30. Lambdaistanbul LGBTT Dayanışma Derneği. "It Iti Isirmaz! Bir Alan Arastirmasi: Istanbul'da Yasayan Trans Kadinlarin Sorunlari.” 2012. Available online: http://www.spod.org.tr/turkce/ eskisite/wp-content/uploads/2012/12/Trans_Anket_Kitab\%C4\%B1_Grafikli.pdf (accessed on 15 July 2013).

31. Yilmaz, Volkan, and İpek Göçmen. "Summary Results of the Social and Economic Problems of Lesbian, Gay, Bisexual and Transsexual (LGBT) Individuals in Turkey Research." Center for Policy and Research on Turkey 4 (2015): 97-105.

32. Gagné, Patricia, and Richard Tewksbury. "Conformity Pressures and Gender Resistance among Transgendered Individuals.” Social Problems 45 (1998): 81-101.

33. Transgender Europe. "Alarming Figures: Over 1700 trans people killed in the last 7 years." 2015. Available online: http://www.transrespect-transphobia.org/uploads/downloads/2015/TMMIDAHOT2015/TMM-PR-IDAHOT2015-en.pdf (accessed on 30 June 2015).

34. Soyle, Firat. "Yargi Homofobik Mi?" 12 October 2011. Available online: http://www.bianet.org/ biamag/diger/133985-yargi-homofobik-mi (accessed on 5 June 2013).

35. BIA Haber Merkezi. "Nefret Cinayetine Iyi Hal Indirimi." 20 July 2012. Available online: http:// www.bianet.org/bianet/hukuk/139825-nefret-cinayetine-iyi-hal-indirimi (accessed on 5 June 2013).

36. Hurriyet Daily News. "Homosexuality Is a Disease' Says Turkish Minister." 7 March 2010. Available online: http:/www.hurriyetdailynews.com/default.aspx?pageid $=438 \& \mathrm{n}=8216$ homosexuality-is-a-disease8217-says-minister-2010-03-07 (accessed on 15 June 2015).

37. Milliyet. “Okan'dan Melih Gökçek’e Şok Gay Sorusu!” 4 March 2012. Available online: http:// www.milliyet.com.tr/okan-dan-melih-gokcek-e-sok-gay-sorusu-/gundem/gundemdetay/02.04.2012/ 1523190/default.htm (accessed on 15 June 2015).

38. Birgun. "Efkan Ala Da Hedef Gösterme Peşinde: Eşcinsel Evlilik Insanlığın Helakıdır." 2 June 2015. Available online: http://www.birgun.net/haber-detay/efkan-ala-da-hedef-gosterme-pesindeescinsel-evlilik-insanligin-helakidir-82104.html (accessed on 15 June 2015).

39. Türkiye Büyük Millet Meclisi. "Türkiye Büyük Millet Meclisi Milletvekilleri Dağılımı.” 2015. Available online: https://www.tbmm.gov.tr/develop/owa/milletvekillerimiz_sd.dagilim (accessed on 30 June 2015).

40. Türkiye Büyük Millet Meclisi. "Meclis Araştırması Önergeleri Bilgileri.” 2013. Available online: https://www.tbmm.gov.tr/develop/owa/meclis_arastirma_onergeleri.onerge_bilgileri?kanunlar_sir a_no=141391 (accessed on 30 August 2013). 
41. Türkiye Cumhuriyeti Anayasası. Available online: https://www.tbmm.gov.tr/develop/owa/ anayasa.uc?p1=10 (accessed on 5 July 2013).

42. Erdemir, Aykan. "CHP Erdemir's Support of CHP Motion to Investigate LGBT Problems.” 2013. Available online: http://gbtinewsturkey.com/2013/08/09/chp-support-lgbt-motion/ (accessed on 30 June 2013).

43. Kurkcu, Ertuğrul. "BDP Kurkcu's Support of CHP Motion to Investigate LGBT Problems.” 2013. Available online: http://lgbtinewsturkey.com/2013/08/09/bdp-support-lgbt-motion/ (accessed on 30 June 2013).

44. Dagoglu, Türkan. “AKP Dagoglu's Rebutal of CHP Motion to Investigate LGBT Problems.” 2013. Available online: http://lgbtinewsturkey.com/2013/08/09/akp-rebuttal-lgbt-motion/ (accessed on 30 June 2013).

45. Islam, Ayşenur. "Turkey's Minister of Family Sees Homosexuality as a 'Preference'." 2015. Available online: http://gbtinewsturkey.com/2015/02/01/turkeys-minister-of-family-seeshomosexuality-as-a-preference/ (accessed on 15 June 2015).

46. Birdal, Mehmet Sinan. "Queering Conservative Democracy." Turkish Policy Quarterly 11 (2013): 119-29.

47. Kaos GL Dernegi. "Demirtaş: LGBTI'lerin Varoluşu Suç Görülüyor.” 2014. Available online: http://kaosgl.org/sayfa.php?id=17094 (accessed on 20 August 2015).

48. Akpinar, Omer. "Kılıçdaroğlu'ndan eşcinsel evlilik yorumu: Herkesin hayatına kimse karışamaz." 2015. Available online: http://kaosgl.org/sayfa.php?id=19175 (accessed on 20 August 2015).

49. LGBTI News Turkey. "22 MPs In Turkey’s New Parliament Will Support LGBTI Rights.” 2015. Available online: http://gbtinewsturkey.com/2015/06/09/mps-in-turkeys-new-parliament-willsupport-lgbti-rights/\#more-2992 (accessed on 1 June 2015).

50. Uluslararasi Af Orgutu. "Trans, Onurlu ve Turkiyeli: Sosyal Adalet icin Sanatsal Bir Mudahale (Proudly Trans in Turkey).” 2013. Available online: https://dl.dropboxusercontent.com/u/ 17328227/Trans_Onurlu_ve_Turkiyeli.pdf(accessed on 20 August 2013).

51. Tar, Yildiz. "Komutandım, trans olduğumu söyleyince her şey sıfırlandı.” 2014. Available online: http://www.kaosgl.com/sayfa.php?id=18192 (accessed on 5 June 2015).

52. Pinto, Rogério M., Rita M. Melendez, and Anya Y. Spector. "Male-to-Female Transgender Individuals Building Social Support and Capital from Within a Gender-Focused Network." Journal of Gay \& Lesbian Social Services 20 (2008): 203-20.

53. Clements-Nolle, Kristen, Rani Marx, and Mitchell Katz. "Attempted Suicide Among Transgender Persons." Journal of Homosexuality 51 (2006): 53-69.

54. Testa, Rylan J., Laura M. Sciacca, Florence Wang, Michael L. Hendricks, Peter Goldblum, Judith Bradford, and Bruce Bongar. "Effects of Violence on Transgender People." Professional Psychology: Research and Practice 43 (2012): 452-59.

55. Haas, Ann P., Mickey Eliason, Vickie M. Mays, Robin M. Mathy, Susan D. Cochran, Anthony R. D’Augelli, Morton M. Silverman, Prudence W. Fisher, Tonda Hughes, Margaret Rosario, and et al. "Suicide and Suicide Risk in Lesbian, Gay, Bisexual, and Transgender Populations: Review and Recommendations." Journal of Homosexuality 58 (2011): 10-51. 
56. LGBT News Turkey. “Transwoman Ends Her Life in Istanbul: I Couldn't, They Didn't Let Me.” 2015. Available online: http://gbtinewsturkey.com/2015/01/05/trans-woman-ends-her-life-inistanbul-i-couldnt-they-didnt-let-me/ (accessed on 20 June 2015).

57. Meyer, Ilan H. "Prejudice, Social Stress, and Mental Health in Lesbian, Gay, and Bisexual Populations: Conceptual Issues and Research Evidence.” Psychological Bulletin 129 (2003): 674-97.

58. Burgess, Diana, Richard Lee, Alisia Tran, and Michelle van Ryn. "Effects of Perceived Discrimination on Mental Health and Mental Health Services Utilization among Gay, Lesbian, Bisexual and Transgender Persons.” Journal of LGBT Health Research 3 (2008): 1-14.

59. Kertzner, Robert M., Mary E. Barber, and Alan Schwartz. "Mental Health Issues in LGBT Seniors." Journal of Gay \& Lesbian Mental Health 15 (2011): 335-38.

(C) 2015 by the author; licensee MDPI, Basel, Switzerland. This article is an open access article distributed under the terms and conditions of the Creative Commons Attribution license (http://creativecommons.org/licenses/by/4.0/). 